Acta Technologica Agriculturae 4

Nitra, Slovaca Universitas Agriculturae Nitriae, 2021, pp. 202-208

\title{
MECHANICAL PROPERTIES OF WHEAT GRAINS AT COMPRESSION
}

\author{
Ĺubomír KUBÍK, Monika BOŽIKOVÁ*, Viera KAŽIMÍROVÁ \\ Slovak University of Agriculture in Nitra, Slovak Republic
}

\begin{abstract}
Hook's law for evaluation of the modulus of elasticity of wheat grains and its general behaviour under compressive loads were studied. Whole specimens were subjected to compressive loading between metal parallel plates. The mechanical properties of grains were determined in terms of average failure strengths of grain bran and whole grain; deformation; and modulus of elasticity. The mechanical properties of very dry grains of the winter wheat Triticum aestivum L. with the moisture content of $10.3 \%$ were studied. The failure strength of grain bran was $4.43 \mathrm{MPa}$ at the deformation of $10.7 \%$, and the failure strength of whole grains was $4.88 \mathrm{MPa}$ at the deformation of $13.5 \%$. The modulus of elasticity of grains was $43.67 \mathrm{MPa}$. The apparent energy density at bran failure strength was $0.261 \mathrm{MJ} \cdot \mathrm{m}^{-3}$, and $0.470 \mathrm{MJ} \cdot \mathrm{m}^{-3}$ on the level of grain failure strength of the whole grain. The bran border structure of central inner part of grains was studied using microscope digital sections of longitudinal cuts of the grains using the image computer processing method. The area proportion of starch and pericarp of the border parts of grains was studied to describe the border texture of central sections of grains.
\end{abstract}

Keywords: wheat; modulus of elasticity; failure strength; apparent energy density; structure

Wheat is exploited mainly for mill-bakery processes. The endosperm of wheat grain comprises approx. $83 \%$ of the kernel weight and is a source of white flour. The endosperm contains the greatest share of protein, carbohydrates, iron and major B vitamins, such as riboflavin, niacin and thiamine. The endosperm is also a source of soluble fibre. Bran makes up approx. $14.5 \%$ of the kernel weight. It contains a small amount of protein, large quantities of the three major B vitamins, trace minerals and dietary fibre primarily insoluble (Flour.com, 2020). Thermophysical parameters are significant characteristics that can be used for improvement of technological processes. If the basic thermal parameters are known, it is possible to determine optimal storage conditions (Božiková et al., 2015). Raw wheat is irreplaceable in production of raised bakery products. Furthermore, it is also used to produce different sorts of bakery products, breakfast cereals, pastries, etc. Wheat utilization is also increased due to food purposes. Wheat grain becomes inseparable component of the feedstuffs; it is used for production of the starch and ethanol (Kulp and Ponte, 2000). Triticum aestivum L. is the most important bread plant. Physical and mechanical properties of grains are necessary for designing the facility of storage, handling and processing of agricultural products (Seifi and Alimardani, 2010). Knowledge of apparent elastic properties such as Poisson's ratio and elastic modulus of agricultural seeds is important for the prediction of their load-deformation behaviour and design of their processing machines. The risk of damaging and cracking the seeds during harvesting, conveying and processing is high. Therefore, to analyse the effect of cracking on deterioration of seed resistance to fracture, it is necessary to determine the fracture characteristics. There is a simple relationship between fracture characteristics and modulus of elasticity. The modulus of elasticity can be determined using different techniques, determination of fracture characteristics is the main benefit of applying fracture method (Khodabakhshian and Emadi, 2011). The mechanical properties of wheat grains have been considered both as single grains, with multiple grains together, and as individual bran layers through multiple approaches. Turnbull and Rahman (2002) studied the complex properties of the wheat texture of endosperm. Compression of the wheat endosperm was studied by Budny et al. (2016) and Dobraszczyk et al. (2002). Tensile loading was applied to whole grains or bran layers (Antoine et al., 2003). Hemery et al. (2010) investigated the fracture mechanics of grains.

The aim of paper was to determine the mechanical properties of winter wheat grains Triticum aestivum L. The properties are relevant in terms of mechanical condition evaluation of grains. The grains were submitted the compression between two parallel steel plates. The stressstrain loading curves were plotted and the failure strengths of grain bran and of whole grain were determined. Moduli of elasticity of grains and the apparent energy densities at failure strength of bran and on the level of grain failure strength were determined. The bran border structure of central inner part of grains was studied on microscope sections of the longitudinal cuts of the grains using image computer processing. The presence area of starch in bran border of the grain central section was selected by the computer image processing. The area proportion of the

Contact address: Monika Božiková, Slovak University of Agriculture in Nitra, Faculty of Engineering, Institute of Electrical Engineering, Automation, Informatics and Physics, Tr. Andreja Hlinku 2, 94976 Nitra, Slovak Republic; e-mail: monika.božikova@uniag.sk 
starch and pericarp in the bran border was studied in order to describe the border texture of central grain sections. Relation study of the border texture to the mechanical properties was conducted. The parameters obtained can be utilized in development of new wheat varieties, comparison with different wheat varieties, and development and construction of mills, storages and equipment for the processing of wheat grains.

\section{Material and methods}

For the purposes of this paper, samples of the hard winter wheat Triticum aestivum L. variety Astella were used. The grains came from Nitra region (Slovakia) and were harvested in 2019. The moisture content of samples at measurement was $10.3 \%$. Seeds and grains differ considerably in structure, they share certain characteristics as they have endosperm tissue adjacent or even encasing the embryo and the dead starchy endosperm; they have a low-hydrated state with usually only $8-12 \%$ moisture content (Budny et al., 2016). Although tempering is a standard procedure for increasing and adjusting the moisture content of wheat before milling (to approx. 16\%), this study observes very dry grains. Water is usually sprayed onto the wheat grains in order to adjust the moisture content by modifying the mechanical properties of grain tissues. This process of starchy endosperm mellowing prior to milling is very important to produce high-quality flour (Hemery et al., 2010). The moisture content was measured by the gravimetric method. The measurement was realized in November 2020. Ten samples were used for measurement. The grains were from ten different ears and ten different parts of field. The longitudinal D1 and lateral D2 diameters were measured for each grain by the caliper with the accuracy of $\pm 0.05 \mathrm{~mm}$. The measured values are introduced in Table 1.

Table 1 Longitudinal $D_{1}$ and lateral $D_{2}$ diameters of wheat grains

\begin{tabular}{|l||c|c|}
\hline $\mathbf{n}$ & $\mathbf{D}_{\mathbf{1}} \mathbf{( \mathbf { m m } )}$ & $\mathbf{D}_{\mathbf{2}} \mathbf{( \mathbf { m m } )}$ \\
\hline $\mathbf{1}$ & 6.6 & 3.50 \\
\hline $\mathbf{2}$ & 6.9 & 3.55 \\
\hline $\mathbf{3}$ & 6.8 & 3.30 \\
\hline $\mathbf{4}$ & 7.0 & 3.75 \\
\hline $\mathbf{5}$ & 7.5 & 3.75 \\
\hline $\mathbf{6}$ & 6.4 & 3.35 \\
\hline $\mathbf{7}$ & 6.5 & 3.45 \\
\hline $\mathbf{8}$ & 7.2 & 3.60 \\
\hline $\mathbf{9}$ & 6.7 & 3.15 \\
\hline $\mathbf{1 0}$ & 6.4 & 3.55 \\
\hline Average & 6.800 & 3.495 \\
\hline SD & 0.114 & 0.060 \\
\hline CV (\%) & 1.670 & 1.725 \\
\hline
\end{tabular}

SD - standard deviation; CV - coefficient of variation
The outer layer or wheat seed covering is called the wheat bran and protects the main part of the kernel. The bran represents approx. $15 \%$ of the seed weight. Bran can be divided into the pericarp which consists of epidermis, hypodermis, cross layer, tube cells, seed coats, and hyaline layer (Budny et al., 2016).

The bran border structure of wheat grains sample was studied by optical microscopy and computer image processing. The grains were cut in two halves in the area of crease. Ten border sections of the central part of grain samples were studied. The images were taken by the Levenhuk DTX 50 digital microscope with the image sensor 1.3 MPix (Levenhuk, TAMPA, USA). The image sizes were $640 \times 480$ pixels and $13.5 \times 10.2 \mathrm{~cm}$. The vertical dimension resolution of images was 4.74 pixels $\mathrm{mm}^{-1}$ and the horizontal direction was 4.70 pixels $\cdot \mathrm{mm}^{-1}$. The images were taken at $135 \times$ magnification. The original images were $1.00 \times$ $0.75 \mathrm{~mm}$. ImageJ FiJi ver. 1.53c software (Schindelin, Open source, USA) was used for processing of images (Rasband, 1997-2018). The segmentation method by thresholding and analysing of particles was conducted, allowing the determination of regions by setting the lower and upper threshold values, segmenting grayscale images (Huang and Wang, 1995). The area proportion of starch and pericarp in bran border was studied to describe the bran structure of central grain sections.

Statical compressive loading in the uniaxial direction was used for grain testing. Testing machine Andilog Stentor 1000 (Andilog Technologies, Vitrolles, France) with software RSIC ver. 4.06) was employed for compression tests. Measured sample was placed between two parallel steel plates - one was fixed rectangular plate and the second was moving circular plate with diameter of $20 \mathrm{~mm}$. The measurement was conducted at the loading speed $10 \mathrm{~mm} \cdot \mathrm{min}^{-1}$. The output values obtained included force $F(N)$ and contraction of the material $\Delta l(\mathrm{~mm})$, which were saved to the excel format. The equipment accuracy was $\pm 0.01 \mathrm{~mm}$ for contraction measurement and $\pm 0.05 \mathrm{~N}$ for force measurement. Subsequently, the stresses and relative contractions or deformation of grains were calculated. Mechanical stress $\sigma$ was calculated (Crandall et al., 1978) as follows:

$$
\sigma=\frac{F}{S}
$$

where:

$\sigma$ - stress in the compression (MPa); $F$ - force $(\mathrm{N})$; $S$ - crosssection of grains $\left(\mathrm{mm}^{2}\right)$

The cross-section of grains was calculated as the area of ellipse:

$$
S=\frac{\pi D_{1} D_{2}}{4}
$$


Mechanical strain is a relative contraction or deformation, and was calculated as follows:

$$
\varepsilon=\frac{\Delta l}{I_{o}}
$$

where:

$\varepsilon$ - strain; $I_{0}$ - initial sample length $(\mathrm{mm}) ; \Delta l$ - contraction $(\mathrm{mm})$

The stress-strain dependencies were obtained from the calculated values. The failure strength was determined by the point in stress-strain diagram after which the stress value decreases and, simultaneously, the strain value increases. The modulus of elasticity was determined on the base of the Hook's law:

$$
\sigma=E \varepsilon
$$

where:

$$
E \text { - modulus of elasticity (MPa); } \sigma-\text { stress }(\mathrm{MPa}) ; \varepsilon-\text { strain }
$$

The slopes of stress-strain diagrams were determined by regression analysis in the linear areas of curves as moduli of elasticity on the base of Eq. 4.

The apparent energy density $W\left(\mathrm{MJ} \cdot \mathrm{m}^{-3}\right)$ at the failure was defined as the total work of deformation in the sample volume (Nedomová et al., 2017):

$$
W=\int_{0}^{\varepsilon} \sigma d \varepsilon
$$

The integral limits were the failure strength values of grain bran and whole grain, respectively.

Pearson coefficient of the correlation $r$ was used for comparison of quantities:

$$
r=\frac{\sum_{i=1}^{n}\left(X_{i}-\bar{X}\right) \times\left(Y_{i}-\bar{Y}\right)}{\sqrt{\sum_{i=1}^{n}\left(X_{i}-\bar{X}\right)^{2} \times \sum_{i=1}^{n}\left(Y_{i}-\bar{Y}\right)^{2}}}
$$

The software Microsoft Office, Microsoft Excel ver. 2010 was used for the calculation.

\section{Results and discussion}

The bran border structure of central inner grain part was studied on the microscope sections of the longitudinal cuts of grains using image computer processing. The presence area of starch regions in bran border of the central grain section was selected by the computer image processing. The area proportion of starch and pericarp in the bran was investigated to describe the border texture of central sections of grains. Ten sections of the bran border of central grain part were studied. The bran structure of wheat grain sample 4 is showed as the central grain part section (Fig. 1). The white part is the starched endosperm and dark parts are the pericarp with crease in the image centre. Structure segmentation of central section of the wheat grain sample

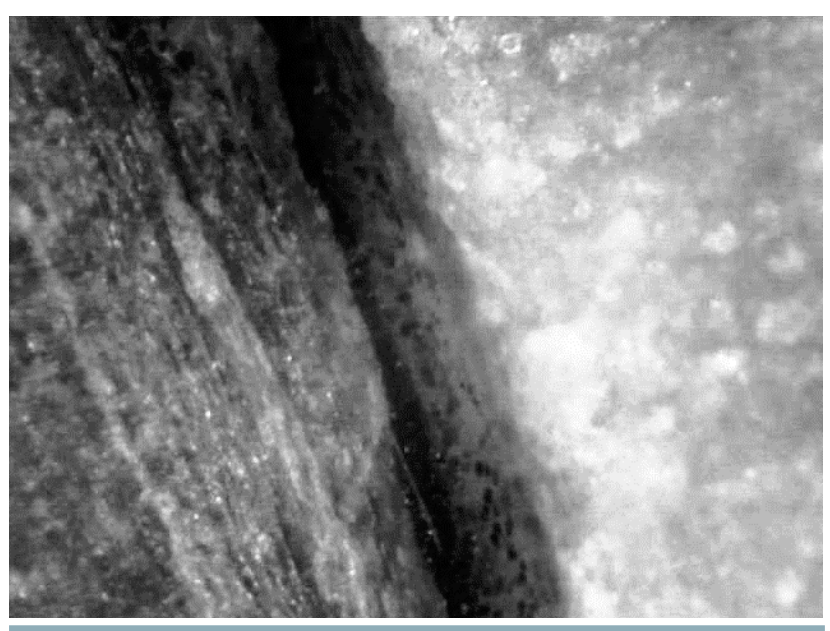

Fig. 1 Bran border section of central inner part of the wheat grain sample 4 with pericarp, crease and starched endosperm

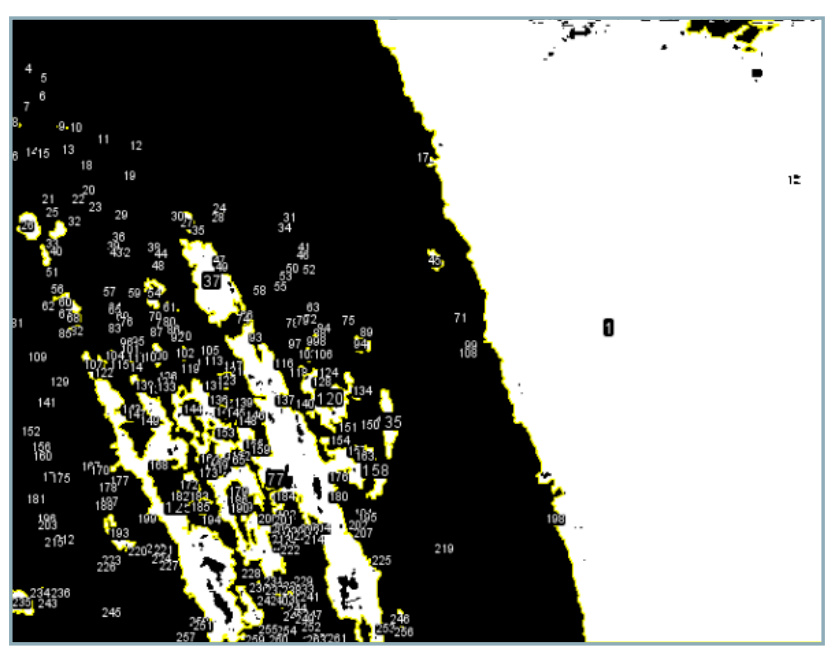

Fig. 2 Segmentation of starched regions of the sample 4 presented by white colour, the crease and the pericarp are marked by black colour

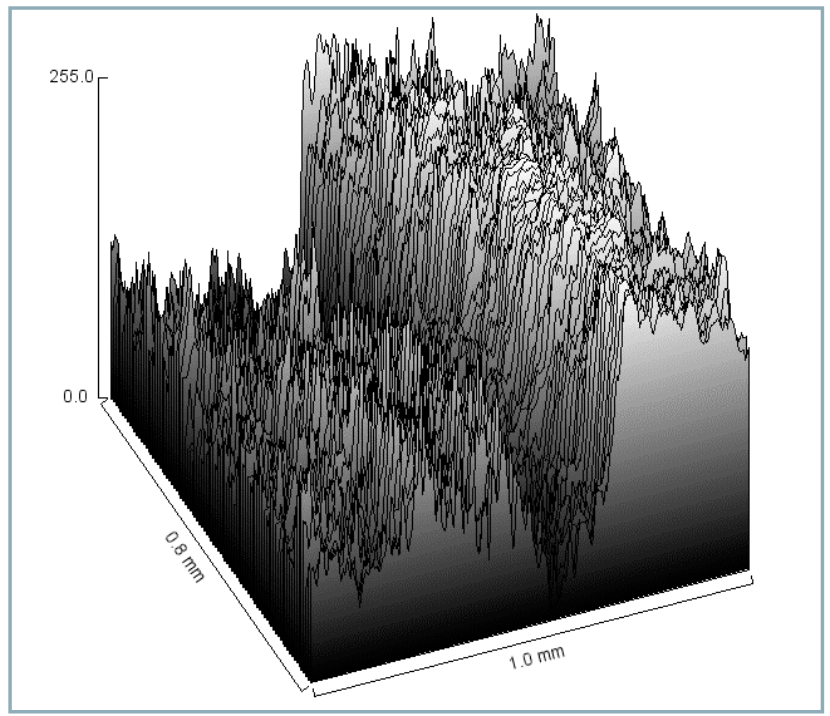

Fig. 3 3D surface of the samle 4 image presented by the grey scale from 0 (black) to 255 (white) 
Table 2 Proportion of the pericarp and the starched endosperm

\begin{tabular}{|c|c|c|c|c|}
\hline Sample & Starched area $\left(\mathrm{mm}^{2}\right)$ & Starched area (\%) & Pericarp area $\left(\mathrm{mm}^{2}\right)$ & Pericarp area (\%) \\
\hline 1 & 0.332 & 44.28 & 0.418 & 55.72 \\
\hline 2 & 0.358 & 47.72 & 0.392 & 52.28 \\
\hline 3 & 0.373 & 49.79 & 0.377 & 50.21 \\
\hline 4 & 0.314 & 41.84 & 0.436 & 58.16 \\
\hline 5 & 0.346 & 46.08 & 0.404 & 53.92 \\
\hline 6 & 0.284 & 37.86 & 0.466 & 62.14 \\
\hline 7 & 0.312 & 41.54 & 0.438 & 58.46 \\
\hline 8 & 0.311 & 41.43 & 0.439 & 58.57 \\
\hline 9 & 0.380 & 50.72 & 0.370 & 49.28 \\
\hline 10 & 0.282 & 37.67 & 0.468 & 62.33 \\
\hline Average & 0.329 & 43.893 & 0.421 & 56.107 \\
\hline SD & 0.011 & 1.461 & 0.011 & 1.461 \\
\hline VC (\%) & 3.328 & 3.328 & 2.604 & 2.604 \\
\hline
\end{tabular}

$\mathrm{SD}$ - standard deviation; CV - coefficient of variation

Table 3 Compressive properties of wheat grains

\begin{tabular}{|l||c|c|c|c|}
\hline $\boldsymbol{n}$ & Defsbran & Stressbran (MPa) & Defgrain & Stressgrain (MPa) \\
\hline $\mathbf{1}$ & 0.120 & 5.12 & 0.260 & 7.77 \\
\hline $\mathbf{2}$ & 0.090 & 3.86 & 0.120 & 4.42 \\
\hline $\mathbf{3}$ & 0.120 & 4.38 & 0.120 & 4.38 \\
\hline $\mathbf{4}$ & 0.096 & 3.98 & 0.120 & 4.34 \\
\hline $\mathbf{5}$ & 0.100 & 4.57 & 0.100 & 4.57 \\
\hline $\mathbf{6}$ & 0.140 & 6.18 & 0.220 & 7.10 \\
\hline $\mathbf{7}$ & 0.110 & 4.61 & 0.110 & 4.57 \\
\hline $\mathbf{8}$ & 0.081 & 3.08 & 0.081 & 3.08 \\
\hline $\mathbf{9}$ & 0.096 & 3.71 & 0.096 & 3.71 \\
\hline $\mathbf{1 0}$ & 0.120 & 4.84 & 0.120 & 4.84 \\
\hline average & 0.107 & 4.433 & 0.135 & 4.878 \\
\hline SD & 0.006 & 0.271 & 0.018 & 0.457 \\
\hline CV (\%) & 5.254 & 6.122 & 13.562 & 9.379 \\
\hline
\end{tabular}

Defsbran - bran deformation at failure; Stresssbran - bran stress = bran failure strength; Defgrain - grain deformation at failure; Stressgrain - grain stress = grain failure strength; SD - standard deviation, CV - coefficient of variation

4 with the starch in the central grain part is presented in Fig. 2. Segmentation of the starched regions is presented by the white colour, the crease and the pericarp by the black colour. The segmentation threshold was given by shades of grey from 131 to 255 . The white regions are numbered for the purposes of counting the separated starched regions. The area proportion of pericarp and starched endosperm is showed in Table 2. Three-dimensional presentation of the section from Fig. 1 is showed in Fig. 3. The vertical axis represents 256 shades of grey (0-255). Image presents the better relief representation of sections.

The vertical dimension of images was 4.74 pixels $\cdot \mathrm{mm}^{-1}$ and the horizontal direction resolution was 4.70 pixels $\cdot \mathrm{mm}^{-1}$. The images were taken with $135 \times$ magnification ( 1 pixel $=$
$0.0015625 \mathrm{~mm})$. The original size of images was $1.00 \times$ $0.75 \mathrm{~mm}$.

The starched and pericarp areas (Table 2) are very proportional. The texture of these areas influences the mechanical properties of grains. Cell-wall composition and architecture of various tissues is known in connection to their mechanical properties for different seed types and cereal grains of species including wheat (Burton and Fincher, 2012). Compression stress-strain diagrams of the wheat grains are presented in Fig. 4, depicting the linear part of curves with the first and the second peaks. The first peak represents the grain bran failure strength and the second represents the failure strength of whole grain. 
The bioyield was not determined as the first peak, because the bran crack was observed at this point. The failure strength values of grain bran and whole grains are presented in Table 3. The failure strengths of bran and whole grains were the same for samples 3,5 , 7, 8, 9 and 10. The very low moisture of grains caused fusion of the failure strengths. The average failure strength values of grain bran and whole grains are very close to each other, the average strain and stress values of grain bran were $10.7 \pm 0.6 \%$ and $4.43 \pm 0.271$ $\mathrm{MPa}$, respectively. Considering the whole grains, the average strain and stress values reached $13.5 \pm 1.8 \%$ and $4.88 \pm 0.457 \mathrm{MPa}$, respectively. Regarding the grain bran, the strain determination variability for failure strengths was $5.3 \%$ and the stress determination variability for failure strengths was $6.1 \%$. In relation to whole grains, the strain determination variability for failure strengths was $13.6 \%$ and the stress determination variability for failure strengths was $9.4 \%$. The variation could be caused by the elliptical cross sections of grains. This problem can be solved by the circular cross-section areas, diameter of which would be equal to the average kernel diameter which is assumed to be the contact surface (Fornal et al., 2000; Kuzminskyi et al., 2018). The differences between cross sections influenced by application of the average circle diameter instead

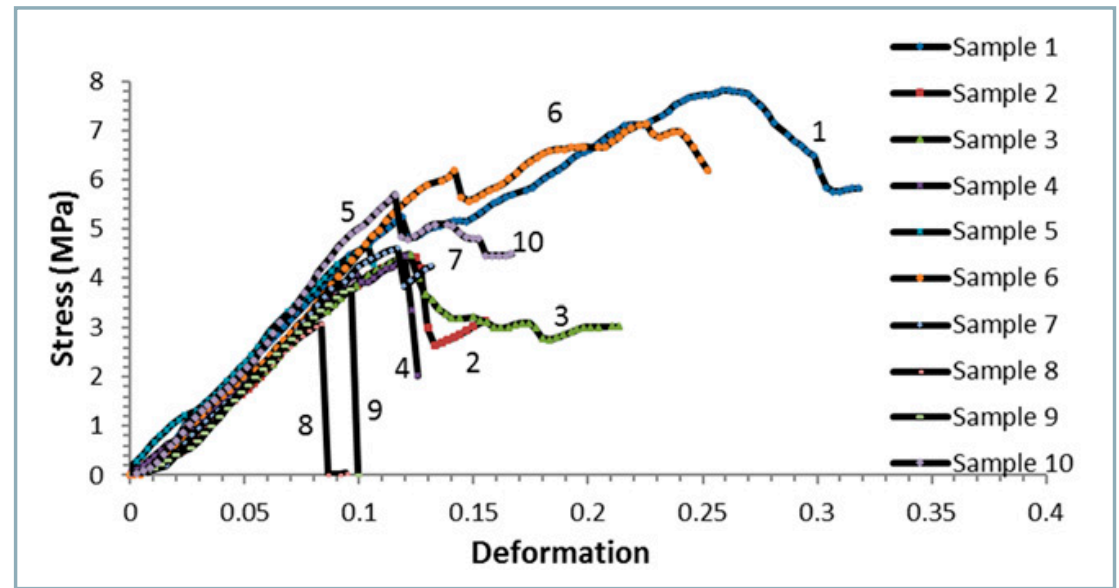

Fig. 4 Compression diagrams of wheat grains

of elliptical parameters ranged from $9 \%$ to $11 \%$. According to Budny et al. (2016), the force required to shear the endosperm and cause the breaking behaviour ranges from 2 to $6 \mathrm{~N}$; in terms of stress, the values range from 0.1 to $1 \mathrm{MPa}$ for the same effect. Furthermore, Barrera et al. (2019) observed the loading forces of hard wheat grains ranging from 70 to $100 \mathrm{~N}$, and the stresses ranging from 3.89 to $5.56 \mathrm{MPa}$.

The variation of failure strength values of whole grains was bigger than the variation of grain bran failure strength values. This was caused by the values obtained for samples 1 and 6, which were shifted in comparison with the values for other samples (Fig. 4).

The moduli of elasticity of wheat grains were determined based on Hook's law from the slopes of linear parts of the stress-strain curves (Fig. 5). The regression equations representing Hook's law are showed in Table 4 with very high coefficients of correlation.

The average whole grain modulus of elasticity value was $43.672 \pm 0.910$ $\mathrm{MPa}$. The determination variability of modus of elasticity reached value of mere $2.1 \%$. The slopes of linear parts of the stress-strain curves from Fig. 4 presented in Fig. 5 were very similar. The modulus of elasticity was determined correctly. Jia et al. (2015) introduced the values of modulus of

Table 4 Determination of apparent energy density and modulus of elasticity

\begin{tabular}{|l||c|c|c|c|c|c|c|}
\hline $\boldsymbol{n}$ & $\begin{array}{c}\text { Regression } \\
\text { equation }\end{array}$ & Defbran & $\begin{array}{c}\text { Wbran } \\
\left(\mathbf{M J . m} \mathbf{m}^{-3}\right.\end{array}$ & Defgrain & $\begin{array}{c}\text { Wgrain } \\
(\mathbf{M J . m} \text { ) }\end{array}$ & $\begin{array}{c}\boldsymbol{E} \\
\mathbf{( M P a )}\end{array}$ & $\boldsymbol{R}$ \\
\hline $\mathbf{1}$ & $y=44.052 x-0.2071$ & 0.120 & 0.317 & 0.260 & 1.489 & 44.052 & 0.994 \\
\hline $\mathbf{2}$ & $y=42.020 x-0.2500$ & 0.090 & 0.170 & 0.120 & 0.303 & 42.020 & 0.993 \\
\hline $\mathbf{3}$ & $y=40.883 x-0.2071$ & 0.120 & 0.294 & 0.120 & 0.294 & 40.883 & 0.994 \\
\hline $\mathbf{4}$ & $y=40.492 x-0.0228$ & 0.096 & 0.187 & 0.120 & 0.292 & 40.492 & 0.994 \\
\hline $\mathbf{5}$ & $y=44.554 x-0.1464$ & 0.100 & 0.223 & 0.100 & 0.223 & 44.554 & 0.998 \\
\hline $\mathbf{6}$ & $y=47.298 x-0.2921$ & 0.140 & 0.464 & 0.220 & 1.145 & 47.298 & 0.988 \\
\hline $\mathbf{7}$ & $y=44.926 x-0.3627$ & 0.110 & 0.272 & 0.110 & 0.272 & 44.926 & 0.997 \\
\hline $\mathbf{8}$ & $y=39.517 x-0.2392$ & 0.081 & 0.130 & 0.081 & 0.130 & 39.517 & 0.990 \\
\hline $\mathbf{9}$ & $y=44.899 x-0.4686$ & 0.096 & 0.207 & 0.096 & 0.207 & 44.899 & 0.994 \\
\hline $\mathbf{1 0}$ & $y=48.081 x-0.1950$ & 0.120 & 0.346 & 0.120 & 0.346 & 48.081 & 0.988 \\
\hline Average & - & 0.107 & 0.261 & 0.135 & 0.470 & 43.672 & \\
\hline SD & - & 0.006 & 0.031 & 0.018 & 0.145 & 0.910 & \\
\hline CV (\%) & - & 5.254 & 11.991 & 13.562 & 30.796 & 2.083 & \\
\hline
\end{tabular}

Defbran - bran deformation at failure; Defgrain - grain deformation at failure; Wbran - bran apparent energy density; Wgrain - grain apparent energy density; $E$ - modulus of elasticity; SD - standard deviation; CV - coefficient of variation; $R$ - correlation coefficient 
Table 5 Correlation between parameters

\begin{tabular}{|l||c|c|c|c|c|c|c|}
\hline & Defbran & Stressbran & Defgrain & Stressgrain & E & Wbran & Wgrain \\
\hline Defbran & 1 & & & & & & \\
\hline Stressbran & 0.934 & 1 & & & & & \\
\hline Defgrain & 0.697 & 0.754 & 1 & & & & \\
\hline Stressgrain & 0.769 & 0.856 & 0.976 & 1 & & & \\
\hline E & 0.652 & 0.720 & 0.346 & 0.487 & 1 & & 1 \\
\hline Wbran & 0.985 & 0.948 & 0.684 & 0.762 & 0.736 & & \\
\hline Wgrain & 0.672 & 0.734 & 0.995 & 0.968 & 0.358 & 0.668 & 1 \\
\hline
\end{tabular}

Defbran - bran deformation at failure; Defgrain - grain deformation at failure; Stressbran - bran failure strength; Stressgrain - grain failure strength; $E$ - modulus of elasticity; Wbran - bran apparent energy density; Wgrain - grain apparent energy density

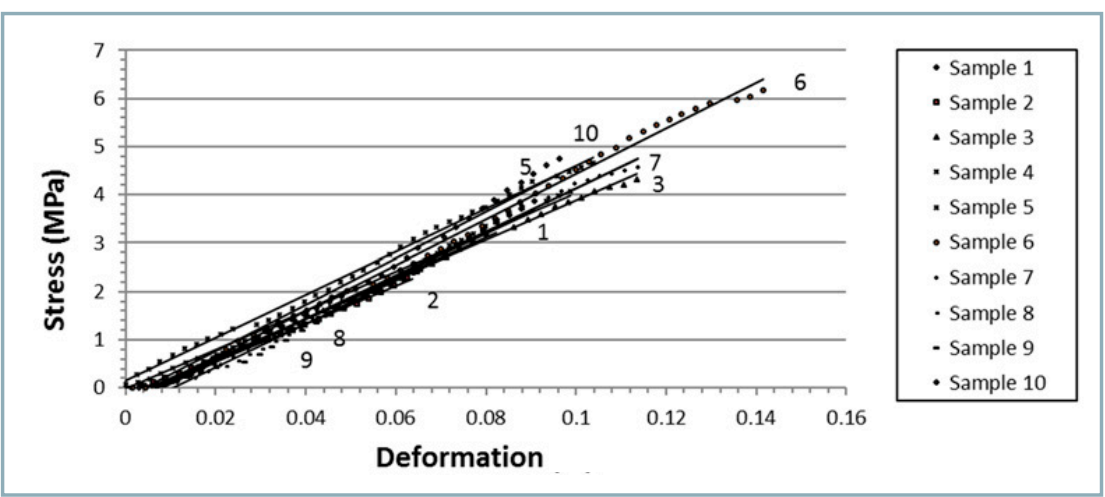

Fig. 5 Determination of the moduli of elasticity of wheat grains on the base of Hook's law

elasticity for wheat of $37 \mathrm{MPa}$, while the wheat moisture content was $10 \%$.

The apparent energy densities of grains calculated using Eq. 5 are presented in Table 4. The apparent energy density expresses the total work of deformation in the sample volume. The average apparent energy density was $0.261 \pm 0.031 \mathrm{MJ} \cdot \mathrm{m}^{-3}$ at the grain bran failure strength of $10.7 \%$, and $0.470 \pm 0.145 \mathrm{MJ} \cdot \mathrm{m}^{-3}$ at the whole grain failure strength of $13.5 \%$. Barrera et al. (2019) introduced the deformation energy of wheat grains of $0.01 \pm 0.004$ J. The variation of average apparent energy density at the grain bran failure strength reached $12.0 \%$. The variation of average apparent energy density at the whole grain failure strength reached $30.8 \%$. The great variability was caused by the greater variability of the failure strength of whole grain, which was represented by the integral limit for energy calculation.

Correlation between compressive parameters is showed in Table 5 . Pearson coefficient of the correlation was used for comparison of quantities. Correlations were calculated using
Microsoft Excel 2010. Very strong correlation (correlation coefficient was greater than 0.8) indicate that there was observed a great relation between the couples of quantities: the stress at the bran failure strength (Stressbran) with the deformation at the bran failure strength (Defbran), and pairs of the apparent energy density of bran (Wbran) with the deformation at the bran failure strength (Defbran). There was observed a very strong correlation between the bran apparent energy density (Wbran) and the stress at the bran failure strength (Stressbran). Concurrently, the same goes for the stress at the whole grain failure strength (Stressgrain) and the deformation at the whole grain failure strength (Defgrain), and the grain apparent energy density (Wgrain) with the stress at the whole grain failure strength (Stressgrain) and the deformation of grain at the failure (Defgrain). The strong correlation (coefficient correlation was greater than 0.6) was reached between all the other pairs with exception of pairs E - Defgrain, E - Stressgrain, and E - Wgrain. The modulus of elasticity showed better relation to the bran parameters than to the parameters of whole grain. The bran and grain parameters showed very strong mutual correlation, indicating that the mechanical properties of both materials were very similar at the moisture content observed.

\section{Conclusions}

Mechanical parameters of the dry $(10.3 \%)$ wheat grains showed that properties of the grain bran and the whole grain are very similar. Several authors achieved similar results for the failure strenght and the deformation energy of wheat grains (Barrera et al., 2019), as well as the modulus of elasticity (Jia et al., 2015). The most consistent was modulus of elasticity. The better variability was reached by the quantities describing the bran than the whole grain. The structure of the central part of grain bran was documented and the proportion of pericarp and starched endosperm was calculated. The mechanical quality of grains is a good indicator for bread loaf volume optimatization and an ultimate criterion for wheat bread making quality. These results provide a foundation for grain damage studies related to grain harvesting and processing operations (Chen et al., 2021). Obtaining of described parameters can serve for the development of new wheat varieties, comparison with different varieties, and design and construction of mills and equipment for processing of wheat grains (Fang and Campbell, 2003). 


\section{Acknowledgements}

This publication was supported by the Operational Program Integrated Infrastructure within the project: Demanddriven research for the sustainable and innovative food, Drive4SIFood 313011V336, co-financed by the European Regional Development Fund.

\section{References}

ANTOINE, C. - PEYRON, S. - MABILLE, F. - LAPIERRE, C. - BOUCHET, B. - ABECASSIS, J. - ROUAU, X. 2003. Individual contribution of grain outer layers and their cell wall structure to the mechanical properties of wheat bran. In Journal of Agricultural and Food Chemistry, vol. 51, no. 7, pp. 2026-2033.

BARRERA, G. N. - MÉNDEZ-MÉNDEZ, J. - ARZATE-VÁZQUEZ, I. CALDERÓN-DOMÍNGUEZ, G. - RIBOTTA, P. D. 2019. Nano- and micro-mechanical properties of wheat grain by atomic force microscopy (AFM) and nano-indentation (IIT) and their relationship with the mechanical properties evaluated by uniaxial compression test. In Journal of Cereal Science, vol. 90, pp. 102830.

BOŽIKOVÁ, M. - HLAVÁČ, P. - VOZÁROVÁ, V. - BELÁŇ, L'. 2015 Experimental determination of soft wheat flour thermal parameters. In Acta Technologica Agriculturae, vol. 18, no. 1, pp. 6-9.

BUDNY, J. A. - FORNAL, J. - OBUCHOWSKI, W. 2016. Analysis of correlations between contents of protein fractions in wheat endosperm models and their mechanical resistance. In Journal of Cereal Science, vol. 71, pp. 10-18.

BURTON, R. A. - FINCHER, G. B. 2012. Current challenges in cell wall biology in the cereals and grasses. In Frontiers in Plant Science, vol. 3, pp. 130.

CHEN, Z. - WASSGRENB, C. - AMBROSE, R. P. K. 2021. Measured damage resistance of corn and wheat kernels to compression, friction, and repeated impacts. In Powder Technology, vol. 380, pp. 638-648.

CRANDALL, S. H. - DAHL, N. C. - LARDNER, J. T. 1978. Introduction to the Mechanics of Solids. Second revised and updated version. New York : McGraw-Hill Publishing Company, 628 pp. ISBN 9780070134416.

DOBRASZCZYK, B. J. - WHITWORTH, M. B. - VINCENT, J. F. V. - KHAN, A. A. 2002. Single kernel wheat hardness and fracture properties in relation to density and the modelling of fracture in wheat endosperm. In Journal of Cereal Science, vol. 35, no. 3, pp. 245-263. FANG, C. - CAMPBELL, G. M. 2003. On predicting roller milling performance $\mathrm{V}$ : effect of moisture content on the particle size distribution from first break milling of wheat. In Journal of Cereal Science, vol. 37, no. 1, pp. 31-41.
FLOUR.COM. Anatomy of a Wheat Kernel. [online]. [cit. 2020-12-03]. Available at: https://flour.com/anatomy-of-a-wheat-kernel/

FORNAL, J. - SADOWSKA, J. - ORNOWSKI, A. - JELIŃSKI, T. VELIKANOV, L. 2000. Damage resistance and microstructure of barley kernels. In International Agrophysics, vol. 14, no. 2, pp. 159-166.

HEMERY, Y. M. - MABILLE, F. - MARTELLI, M. R. - ROUAU, X. 2010. Influence of water content and negative temperatures on the mechanical properties of wheat bran and its constitutive layers. In Journal of Food Engineering, vol. 98, pp. 360-369.

HUANG, L. K - WANG, M. J. J. 1995. Image thresholding by minimizing the measure of fuzziness. In Pattern Recognition, vol. 28, no. 1, pp. 41-51.

JIA, F. - ZHOU, X. - CHEN, F. - WANG, J. 2015. The calculations and simulation testing on the elastic modulus of wheat. In Interdisciplinary Sciences: Computational Life Sciences, vol. 7, pp. 200-204.

KHODABAKHSHIAN, R. - EMADI, B. 2011. Determination of the modulus of elasticity in agricultural seeds on the basis of elasticity theory. In Middle-East Journal of Scientific Research, vol. 7, no. 3, pp. 367-373.

KULP, K. - PONTE, J. G. 2000. Handbook of Cereal Science and Technology. Second edition revised and expanded. New York : Marcel Dekker, 790 pp. ISBN 0824782941.

KUZMINSKYI, R. - KOVALISHYN, S. - KOVALCHYK, Y. - SHEREMETA, R. 2018. Mathematical models of geometric sizes of cereal crops' seeds as dependent random variables. In Acta Technologica Agriculturae, vol. 21, no. 3, pp. 100-104.

NEDOMOVÁ, Š. - KUMBÁR, V. - PYTEL, R. - BUCHAR, J. 2017. Mechanical properties of sugar beet root during storage. In International Agrophysics, vol. 31, no. 4, pp. 507-513.

RASBAND, W.S. 1997-2018. ImageJ, U. S. National Institutes of Health, Bethesda, Maryland, USA, [online]. [cit. 2021-03-16]. Available at: https://imagej.nih.gov/ij/

SEIFI, R. M. - ALIMARDANI, R. 2010. The moisture content effect on some physical and mechanical properties of corn: A review. In Journal of Agricultural Science, vol. 2, no. 4, pp. 125-134.

TURNBULL, K. M. - RAHMAN S. 2002. Endosperm texture in wheat. In Journal of Cereal Science, vol. 36, no. 3, pp. 327-337. 